\title{
Between Sexual Violence and Autonomy: Rethinking the Engagement of the Indian Women's Movement with Criminal Law
}

\author{
Kalika Mehta ${ }^{1}$ and Avantika Tiwari ${ }^{2}$ \\ ${ }^{1}$ Albrecht Mendelssohn Bartholdy Graduate School of Law, University of Hamburg, Hamburg, Germany and ${ }^{2}$ Jindal Global \\ Law School, OP Jindal Global University, Sonepat, India \\ Corresponding author: kalikamehta04@gmail.com
}

(Received 06 July 2021; accepted 07 July 2021)

\begin{abstract}
The aftermath of protests triggered by a brutal gang-rape in New Delhi in December 2012 was archetypal of the broader women's movement in post-independence India. The primary demands of the social movement to address sexual violence against women were wrapped in the language of rights-based reforms in criminal law provisions. The state responded to the social mobilization in the form of criminal law amendments, while blindsiding key recommendations from feminist groups. This Article revisits pertinent Law Commission reports, subsequent criminal law reforms, and case law on sexual violence against women to analyze how the negotiations between the women's movement and the State on the seemingly irreconcilable demands of sexual autonomy and punishment for sexual violence. We take account of the intended and unintended consequences of this reliance on criminal law as one of the primary tools in the arsenal of Indian women's movements. We argue that engagement on the plane of criminal law to address sexual violence against women is a case of limited imagination at best and counter-productive at its worst. This approach of the movement and feminist groups is to react to the "crime" of sexual violence after the fact, leading to distraction from much warranted structural responses. We argue that this approach makes it harder to conceptualize and implement more forward-looking relational models of responsibility that are necessary to address the structural injustice of systemic sexual violence against women.
\end{abstract}

Keywords: Indian Women's Movement; Feminism and Law; Criminal Law Amendments; Relational Responsibility

\section{A. Introduction}

In September 2020, India witnessed another episode of mass protest in response to the gang-rape and killing of a Dalit girl ${ }^{1}$ in the state of Uttar Pradesh. The last time the country was jolted into mass protests over sexual violence against women was in December 2012 triggered by a brutal

\footnotetext{
${ }^{1}$ Dalit communities - also known as untouchables_languish at the bottom of the social structure, organized on the basis of caste, resulting in centuries of systematic discrimination and exploitation. Dalit women, owing to their precarious social and economic situation, are disproportionately targeted when it comes to sexual violence. When an upper-caste perpetrator assaults a Dalit woman, sexual violence becomes a tool of domination not only against the woman but on the Dalit community per se.
}

(C) The Author(s) 2021. Published by Cambridge University Press on behalf of the German Law Journal. This is an Open Access article, distributed under the terms of the Creative Commons Attribution licence (http://creativecommons.org/licenses/by/4.0/), which permits unrestricted re-use, distribution, and reproduction in any medium, provided the original work is properly cited. 
gang-rape of a medical student in New Delhi. ${ }^{2}$ In 2020, the confirmation of death sentences for the perpetrators re-ignited the long-standing debate ${ }^{3}$ on whether feminist movements' reliance on criminal law sanctions serves an emancipatory purpose. How do the demands for capital punishment or stricter punishments for rape made by the social movements impact feminist politics and the ways in which the State addresses violence against women? To engage with this question in the Indian context, this article revisits the social movement and protests triggered in December 2012 concerning sexual violence against women, their outcome in the form of legislative amendments in criminal law concerning rape and sexual violence against women, and the implications of these developments on the Indian women's movement. The relationship of social movements and women's rights groups within the broader Indian women's movement has taken different forms in post-Independence India. On one hand, episodic social movements advocating for women's safety place considerable weight on the concerns of feminist rights groups/organizations. On the other hand, the responses they seek end up weakening the feminist cause of challenging systemic sexual violence. Often, feminist groups find themselves trying to find a middle ground with a State willing to please their political constituency by strengthening its monopoly on violence. Through analyzing this constant negotiation between feminist groups and the state in the framework of criminal law, we argue that there needs to be a shift from criminal liability to a relational responsibility framework to sustainably address sexual violence against women.

The case which sparked mass protests in 2012 concerned the rape and murder of a woman named Jyoti. She was a 23-year-old physiotherapy student returning from a movie evening with a male friend when she got on a private bus to get home. Five men pretending to be passengers beat up Jyoti's friend and threw him off the bus to rape her inside the moving bus. The bus did rounds on the streets of Delhi while the men took turns sexually assaulting her and inflicting serious injuries. Found on the streets stripped naked and bleeding later that night, she succumbed to her injuries two weeks after the incident. ${ }^{4}$

News of this horrid incident spurred spontaneous massive demonstrations and protests across all major cities in the country, with Delhi as the epicenter. ${ }^{5}$ For the first time, the public sphere witnessed the modern Indian woman, on this scale and intensity, calling for justice in the form of retribution and legal reform. The protestors represented the archetype of the young, modern Indian woman-educated, employed, with a new degree of freedom and mobility, yet fundamentally threatened by violence on the streets. ${ }^{6}$

The story of Jyoti, the eldest daughter of a lower-middle class family from a small town who had moved to Delhi to study medicine, become a doctor, and hopefully earn enough to be able to support the education of her younger siblings was emblematic. Not only did she share the aspirations of millions of young Indian women, but her tragic fate recalled the everyday horrors of women who find themselves in the same situation on a daily basis but who manage to barely escape the same fate.

As much as these protests were a result of rage against sexual violence, they were also an expression of the sexual autonomy and bodily integrity of millions of young women struggling to break

\footnotetext{
${ }^{2}$ Mukesh v. State of NCT of Delhi, Supreme Court Order, W.P. (Crl.) No.-000119 (India) (Mar. 19, 2020), https:// indiankanoon.org/doc/88273422/.

${ }^{3}$ Nivedita Menon, Embodying the Self: Feminism, Sexual Violence and the Law, in COMmunity, Gender AND VIOLENCE 74 (Partha Chatterjee \& Pradeep Jeganathan eds., 2000).

${ }^{4}$ See Mukesh v. State for NCT of Delhi, (2017) 6 SCC 1 (India).

${ }^{5}$ Lauren Frayer \& Bobby Allyn, India Sets Executions for the 4 Men Convicted in New Delhi Bus Rape and Murder, NPR (Jan. 7, 2020), https://www.npr.org/2020/01/07/794247034/india-sets-executions-for-the-four-men-convicted-in-new-delhi-busrape-and-murde.

${ }^{6}$ See generally Ratna Kapur \& Brenda Cossman, Subversive Sites 20 Years Later: Rethinking Feminist Engagements with Law, 44 Australian Feminist L.J. 2 (2018), 265-87; Urvashi Butalia, December 16th 2012: A Rape, a Murder and a Movement, Feminism \& Gender Democracy Resource, Gunda Werner Institute, Heinrich Böll Foundation (Apr. 2, 2014), https://www.gwi-boell.de/sites/default/files/uploads/2014/04/december_16th_2012_a_rape_a_murder_and_a_movement.pdf.
} 
away from the patriarchal foundations of Indian culture. The presence of thousands of women protestors demanding sexual autonomy and freedom on the streets marked a transformation in the dominant understanding of Indian womanhood. In some ways, this expression marked a significant departure from the traditional notion of 'self-sacrificing, dutiful, honorable, heterosexual, and most importantly, chaste woman.' This idea of the chaste honorable woman was integral to the struggle for freedom against British colonialism and integral to strengthen a national identity of the Indian woman that was distinct from "the West."

The Indian state, however, struggles to reconcile between the public outcry against sexual violence targeting women and the feminist demands for sexual autonomy. This confusion between demands of grassroots movements, feminist ideals, and a patriarchal state becomes most visible in how the legislature and courts conceive the idea of "consent" in cases of sexual violence. We trace the history of the Indian women's movement, the formation and evolution of women's groups, and their engagement with the State in addressing sexual violence, taking account of the intended and unintended outcomes of the social movement triggered in 2012. We argue that the social movements, women's groups, and the state should consider shifting from a backward-looking liability framework to a collective responsibility framework in order to address the structural injustice that is the root cause of widespread sexual violence against women in India.

\section{B. The Indian Women's Movement}

We must begin with a disclaimer: It is difficult to see the Indian women's movement through the standard prism of international feminist waves or a comparable framework. The identity of the quintessential Indian woman is determined across diverse axes of caste, class, color, language, and religion. Thus, no standard set of demands for justice has ever comprehensively addressed the struggles of the "Indian woman." In other contexts, feminist scholars and activists have highlighted the perils of reducing the social collective to a singular identity. ${ }^{8}$ Owing to the diversity of this social collective, an intersectional analysis is particularly urgent in the case of India. Unsurprisingly, this diversity is reflected by the lack of consensus in the demands of the Indian women's movement. ${ }^{9}$ The politics of women's rights groups varies widely depending on the caste, class, and region on whose behalf they are speaking. Without intending to engage in an act of co-optation or erasure of the diversity of women rights groups in India, we are only looking at the means adopted by the feminist groups to achieve emancipatory goals. Some of these means, particularly to engage with the state, have some common attributes which are the focus of our analysis.

\section{1970s-1980s: Episodic Campaigns for Legal Reforms}

Broadly, feminist initiatives in post-colonial India can be traced back to the 1970s where social movements began to be self-consciously feminist, centered around physical and sexual violence

\footnotetext{
${ }^{7} \mathrm{Up}$ until independence, the women's movement per se was closely aligned with the freedom movement and had to necessarily locate its work in the broader political struggle. See Ratna Kapur, Gender, Sovereignty, and the Rise of Sexual Security Regime in International Law and Postcolonial India, 14 Melbourne J. INT'L L. 317, 343 (2013).

${ }^{8}$ See generally Chandra Mohanty, Linda Nicholson, \& Steven Seidman, Feminist Encounters: Locating the Politics of Experience, in SOCIAL postmodernism: Beyond identity politics 68-86 (1995); Judith Butler, Gender Trouble: FEMINISM AND THE SubVersion Of IdENTITy (2011); Kimberle Crenshaw, Mapping the Margins: Intersectionality, Identity Politics, and Violence Against Women of Color, 43 STANFORD L. REv. 1241 (1990).

${ }^{9}$ Dalit feminists, such as Cynthia Stephen, would rather prefer the term "Dalit Womanism" for their politics, because it affirms the Dalit woman in a more holistic manner rather than the term "feminism," which fails to be inclusive of the Dalit aspiration. See generally, Cynthia Stephen, Feminism and Dalit Women in India, CounTerCurrents (Nov. 16, 2009), http:// www.countercurrents.org/stephen161109.htm.
} 
against women both within and outside the home. ${ }^{10}$ Autonomous women's movements in the 1970s primarily agitated against custodial rape. ${ }^{11}$ Two cases of the Supreme Court's acquittal of police officers for rape in custody - of Rameeza Bee, a young Muslim woman in $1978^{12}$ and of Mathura, a young tribal woman in $1980^{13}$ - galvanized a national campaign demanding legal reforms of rape laws.

In acquitting the accused police officers, the Court emphasized the victim's sexual history and promiscuous character to infer consent over clear evidence of rape and assault. ${ }^{14}$ This reasoning adopted by the Supreme Court became the catalyst to challenge the archaic legal and social understandings of rape and consent derived from the Indian Penal Code (IPC), drafted by the British in 1860. Consent in rape cases was outrageously simplified and could be implied from a mere absence of injuries. Therefore, the ensuing national campaign focused on expanding the definition of rape as well as the understanding of female sexuality.

The initial feminist response took the form of "An Open Letter to the Chief Justice of India" written by four law professors in 1979, ${ }^{15}$ which triggered a public outcry as well as formation of multiple women's rights groups, such as: Forum Against Oppression of Women (Mumbai), Manushi, Saheli (Delhi), Stree Shakti Sangatana (Hyderabad), and Vimochana (Bangalore).

On the one hand, the open letter from the law professors emphatically differentiated between consent and submission. It proposed the idea that "consent involves submission, but the reverse is not true. Hence, absence of resistance does not necessarily indicate consent." ${ }^{16}$ At the time, this letter marked a paradigm shift from the prevalent judicial discourse that insisted on physical signs of injury and clear signs of resistance as the sine qua non for establishing non-consent in cases of rape. On the other hand, the coinciding feminist led-social movement placed the issue of rape and sexual violence in the public domain.

Women's groups used this opportunity and attention from the State to push for a broader campaign that sought legislative reforms. The mobilization of organizing sit-ins, poster campaigns, and writing opinion pieces managed to move the government to set up a Law Commission inquiry which would recommend amendments to the existing criminal law provisions concerning rape and sexual assault. $^{17}$

The Law Commission Report of 1980 was a significant document in so far as it was the first detailed report to include consultations with women's organizations, marking the first explicit engagement of the movement with the State. ${ }^{18}$ It focused exclusively on rape laws, addressing issues ranging from consent to burden of proof to procedural safeguards. Minding the recommendations of women's organizations, the report recommended substituting "free and voluntary consent" for the word "consent." The Commission asserted that:

\footnotetext{
${ }^{10}$ See generally New Feminisms in South Asian Social Media, Film, and Literature: DisRuPting the Discourse (Sonora Jha \& Alka Kurian eds., 2017). The 1950s and 1960s witnessed a radical feminist wave embodied in anti-class and anti-caste struggles.

${ }^{11}$ Rameeza Bee, 1978; Mathura, 1980; Suman Rani, 1988; Kalpana Kannabiran, India, in FEMINIST Advocacy, FAMILY LAW AND Violence Against Women: International Perspectives (Mahnaz Akhami, Yakın Ertürk \& Ann Elizabeth Mayer eds., 2019)

${ }^{12}$ Returning home from a late-night movie with her husband, Ahmad Hussain, Rameeza was arrested and raped by four policemen. The Supreme Court acquitted the policemen and initiated proceedings against Rameeza for engaging in prostitution.

${ }^{13}$ Tuka Ram \& Anr v. State of Maharashtra, (1978) 1979 SCR(1) 810 (India). Mathura was a poor, orphaned tribal girl between fourteen and sixteen years of age when she was raped by the two constables at night inside the Desai Ganj police station.

${ }^{14}$ The Court stated that Mathura was "habituated to sex" such that she did not "raise an alarm for help" and there was an "absence of injuries on her body or signs of struggle." Id.

${ }^{15}$ Upendra Baxi, Lotika Sarkar, Vasudha Dhagamwar, \& Raghunath Kelkar, An Open Letter to the Chief Justice of India, SCC 1:17 (1979), https://aud.ac.in/uploads/1/admission/admissions2014/open\%20letter.pdf.

${ }^{16}$ Baxi et al., supra note 15.

${ }^{17}$ The religious and tribal identity of the two victims, and the disproportionate marginalization they would have faced by virtue of their identity, were not points of discussion in this campaign. See generally Flavia Agnes, Women's Rights and Legislative Reforms: An Overview, 36 InT'L J. LEGAL INFO. 265 (2008).

${ }^{18}$ Law Commission of India, 84th Report on Rape and Allied Offences: Some Questions Of Substantive Law, Procedure and Evidence (1980), http://lawcommissionofindia.nic.in/51-100/Report84.pdf.
} 
[T] his would make it clear that the consent should be active consent, as distinguished from consent which is said to be implied by silence. Under the amendment as recommended, it would not be open for the court to draw an inference of consent from her silence due to timidity or meekness or from such circumstance without anymore, - as the girl meekly followed the offender when he pulled her, catching hold of her hand, or that the women kept silent and did not shout out or protest or cry out for help. ${ }^{19}$

While the Government recommended adopting the definition of consent as "free and voluntary" in the 1980 Criminal Law Bill (Amendment), it was ultimately rejected by the Joint Committee of Parliament. As a result, the definition of "rape" and understanding of "consent" remained unchanged, and the State only added more categories to the offense of rape and sexual violence.

Notwithstanding the subsequent disappointments in the final amendment, feminist recommendations were already filtered out in the negotiations with the Law Commission for itself, while responding to the women's movement demand of adding recklessness as a culpable mental element, theorized rape as a result of "uncontrollable passion or lust of a savage and his approach to the act of rape is a mechanical, non-emotional one." ${ }^{20}$ Making recklessness a culpable mental element would have included cases where the sexual act was performed in callous disregard of female desire. However, when the Commission describes rape as an act of passion it places men at the center of the discourse on rape. It completely erases the possibility of making space for discussion on what the woman wanted. Theorizing a rapist as a lustful individual completely obliterates the pervasive multifaceted nature of sexual violence in a patriarchal structure. While constructing the rapist as nonhuman, the savage other, the Law Commission saw rape fundamentally as a law-and-order problem, rather than that of structural male dominance and the inequality and oppression of women. The report also explicitly rejected women's organizations' proposals to spell out the distinction between "passive submission" and "consent" by way of an explanation — as it exists now after the Criminal Law Amendments of 2013. The rationale given by the Commission was that the term "free and voluntary consent" is wide enough to include all categories of duress. ${ }^{21}$

While responding to this reasoning of the Commission, the feminist interventions end up bending down to this narrative. Their emphasis falls exclusively on finding adequate responses to the law-and-order problem rather than on addressing factors which enable this violence.

\section{1990s-2000s: Flirting with International Legal Frameworks}

Anti-rape campaigns in the 1980s were too episodic and sporadic for them to be transformed into a genuine civil rights issue. ${ }^{22}$ This fragmented mobilization, however, represented a politics of the possibility to use social mobilization as a tool to engage with the state. To add to the complexity, economic liberalization in the 1990s led to an influx of western donor funding which gave rise to a new "funded" form of non-governmental organizations. With more money came institutionalization and more defined structures and spaces. Distinguishing between the newly funded, formal NGOs and the women's rights groups which were leading the movement in previous decades became increasingly difficult. The movement, in fact, lost its fluidity and openness of social groups, as was the case in 1970 s in the NGOization ${ }^{23}$ process. According to some, the

\footnotetext{
${ }^{19}$ Law Commission of India, supra note 18 , at 6.

${ }^{20}$ Law Commission of India, supra note 18 , at 8.

${ }^{21}$ Law Commission of India, supra note 18 , at 8 .

${ }^{22}$ See generally Mangala Subramaniam, The Indian Women's Movement, 33 ConTEMP. Socio. 635 (2004); Srila Roy, The Indian Women's Movement: Within and Beyond NGOization, J. S. AsIAN DEv. 10.1, 96-117 (2015).

${ }^{23}$ The term "NGOization" is not employed in current conversations around Indian feminism as a descriptive term referring to an increase in the number of NGOs working on women rights issues, but as an ideologically and morally evaluative accusation that "understands this phenomenon as harmful for feminism." Sadia Hodzic, Feminist Bastards: Toward a Post-Humanist Critique of NGOization, in ThEORIZING NGOs: STATES, Feminisms, AND NEOLIBERALISM 222 (Victoria Bernal \& Inderpal Grewal eds., 2014).
} 
NGOization led to a relegation of autonomy and agency to external, State and non-State, actors and the resulting reliance on the vocabulary of universal women's rights as human rights led to an undermining of the essence of a genuine feminist movement in India after it peaked in the 1970s, the 1980s, and the early 1990s. ${ }^{24}$ In scholarship, parallels of co-optation and erasure have also been drawn with the "NGO boom" in the Latin American context that took place in the 1980 s. $^{25}$

The vocabulary of international human rights and protection may offer considerable leverage to women's rights groups when engaging with international organizations, donors, and States for their support, welfare programs, and capacity building. However, the struggle of the Indian woman cannot be comprehensively articulated in the limiting language of international human rights treaties. They may serve as a blueprint setting the overarching goals of the movement, but their general framework seems severely inadequate to address the specific needs of marginalized Indian women caused by a combination of factors including caste, class, tribe, and religion. A protection of right against discrimination on the basis of gender and establishing rights of women on an equal basis does not capture the different experiences of oppression of a Hindu upper-caste woman and a Muslim, Dalit, or tribal woman. Moreover, the unenforceability of these international agreements and the Indian state's disregard of the international human rights framework in general ${ }^{26}$ further add to the limitations of this approach. Regardless, the articulation of rights-based demands for legal reforms made by women's groups can be largely attributed to this phase.

\section{2000s: Courting Sexual Consent}

Another significant moment when the women's movement turned to criminal law was when NGO Sakshi filed a petition before the Supreme Court of India in 1999. The petition sought to broaden the definition of penetration in rape law beyond the phallocentric penile-vaginal model. ${ }^{27}$ Sakshi, the NGO, argued that restricting the definition of rape to penis-vagina penetration ignores the contemporary understanding of rape as an attack on the dignity of women, rather than a mechanical physical act. Though the court did not pass any immediate orders, it directed the Law Commission to analyze the multiple issues which came up in the discourse around Section 375 of Indian Penal Code. ${ }^{28}$ Consequently, in 2000 the 172nd Law Commission report recommended that the term "sexual intercourse" in Section 375 be read to include not only penile vaginal penetration but other forms, including digital, oral penetration, anal penetration, and penetration with objects. ${ }^{29}$ However, the report also recommended to make the offense gender-neutral, negating all forms and levels of gendered violence. ${ }^{30}$

The Law Commission report was also important as it was the first time a government body formally contemplated the removal of the marital rape exception. This exception provides that it is not an offense under Indian criminal law for a husband to rape his wife unless the woman

\footnotetext{
${ }^{24}$ See generally Alka Kurian, Decolonizing the Body: Theoretical Imaginings on the Fourth Wave Feminism in India, in NEw Feminisms in South Asian Social Media, Film, And Literature 15-41 (2017).

${ }^{25}$ See Roy, supra note 22, at 98. See generally Sonia E. Alvarez, Advocating Feminism: Latin American Feminist NGO 'Boom', InT'L Feminist J. Pol. 1:2, 181-209; KAREN Engle, The Grip of SEXual Violence in Conflict: Feminist InTERVENTIONS IN INTERNATIONAL LAW (2020).

${ }^{26}$ Although India is a State Party to core human rights treaties, including the Convention on the Elimination of Discrimination against Women (CEDAW), it has not ratified most of its additional protocols, which allow international human rights committees to have jurisdiction over the individual cases of violations.

${ }^{27}$ Sakshi v. Union of India, (1999) 6 SCC 591 (India).

${ }^{28}$ Section 375 of the Indian Penal Code defines the offense of rape. PEN. CODE. $\$ 375$ (India).

${ }^{29}$ Law Commission of India, 172nd Report on Review of Rape Laws, ch. 1, paras. 1-6 (2000).

${ }^{30}$ The consultations with the groups were only held with a limited number of organizations, including Sakshi. The other groups later wrote to the law minister welcoming the overall reform but registering their concerns about substance. See Sadhna Arya \& Vrinda Grover, Re:Response to the 172nd Report of the Law Commission of India, FEMINIST LAW ARCHIVES (Jan. 10, 2002), https://feministlawarchives.pldindia.org/wp-content/uploads/Reposnes-to-the-172nd-Report-ofthe-Law-Commission-of-India.pdf, for the letter sent by Saheli (Delhi), Awaaz-e-Nissan (Mumbai), and others.
} 
is a minor. The line of argument adopted by women's groups such as Sakshi and others, was that if marriage is not an exception for any other physical injury resulting in an offense, then why should the status of "husband" of the victim be an extenuating circumstance for the perpetrator of a sexual offense. ${ }^{31}$

However, the Law Commission rejected this argument on the grounds that removing the exception would lead to excessive interference in marital relationships. ${ }^{32}$ The perceived sacrosanct status of marriage made it extremely difficult for the Law Commission to conceive of non-consent within the context of marriage. Deductively, according to the Commission, consent in rape cases is about marriage rather than freedom of choice.

Since the 1970s, the Indian women's movement, in its various forms, had been engaging with the State to seek legislative reforms and criminal law amendments. With the help of social mobilization, women's rights groups would manage to get the State to respond, but their already limited demands were met with minimal amendments and almost no change in the way the law perceived the problem.

Even though such engagement with the State has always been fraught with contradictions, it is only through engaging and creatively negotiating with the tensions that the Indian feminists have hoped to build a more sustained movement. It is against this backdrop of small victories earned while engaging with the State, that the 2012 protests should be viewed as a turning point for the Indian women's movement.

\section{B. 2012 Protests: Assessing the Intended and Unintended Consequences of a Social Movement}

Although the 2012 protests were unprecedented in scale, they followed the textbook pattern of the broader Indian feminist movement in the past on two counts: One, the diverse nature of the demands - reflecting varying politics - and two, the reliance on criminal law reforms as the means to achieve social justice.

Despite being initiated by the students of Delhi-based Jawahar Lal Nehru University (JNU), this massive social mobilization was not spearheaded by a specific authority, group, or organization. The protest sites in central Delhi became a beehive of students, their political associations, young professionals, women's organizations, unaffiliated alliances, and activists. ${ }^{33}$ For the first time, the protests turned into a broad-based, nation-wide, intersectional, anti-rape movement.

The voices of the demonstrations were interwoven with the democratic spirit, where the language of rights became a tool to claim bodily integrity. Some of the placards emblematically read "My Body, My Right, My City, My Right," "Mahilaein mange azadi, sadak pe chalne ki, raat mein nikalne ki, kuch bhi pehenne ki" ("Women demand freedom, to walk on the streets, to go out at night, to wear anything they like"). ${ }^{34}$ Where these slogans emanated from and catered to the urban masses on the streets, the unanimous demand was an end to the State's indifference to sexual violence, claiming that it denies women their right to life. ${ }^{35}$ Similarly, the protestors called for accelerated proceedings and stricter punishments, including the death sentence. Liberal human rights, which were protected by the criminal legal framework, became the preferred response from the State. ${ }^{36}$ Such appeals were, to an extent, reflective of the belief that acknowledgement and

\footnotetext{
${ }^{31}$ Arya \& Grover, supra note 30.

${ }^{32}$ Arya \& Grover, supra note 30.

${ }^{33}$ For a first-hand account on the semiotics of this protest, see Subir Rana, Visualizing the Semiotics of Protest: The 'Nirbhaya' Rape Case, 27.1 Indian J. Gender STUd. 141 (2020).

${ }^{34}$ Rana, supra note 33; Delhi Rape Victim Passes Away: Posters Speak More Than Words, Econ. Times (Dec. 30, 2012), https://economictimes.indiatimes.com/nation-world/delhi-rape-victim-passes-away-posters-speak-more-than-words/ slideshow/17808950.cms.

${ }^{35}$ See generally Kurian, supra note 24.

${ }^{36}$ Oishik Sircar, Spectacles of Emancipation: Reading Rights Differently in India's Legal Discourse, 49.3 OsGOOD HALL L.J. 527, 550 (2012).
} 
enforcement of these rights by the authority of the State can address systemic oppression resulting in structural injustice. The social movement, seeking action by the State in the form of a legal response, was very limited in its imagination and articulation of its demands.

It is important to note that these were only revenge-filled voices of the protestors that sought castration and public hanging of the perpetrators. ${ }^{37}$ It is important to highlight that the women rights groups and feminist scholars have always distanced themselves from such popular demands to which the State often ends up responding.

\section{Negotiating Concessions: The Justice Verma Committee}

True to its form, the immediate response of the government to the protests was to adjust the criminal justice mechanism as the primary solution to address the "epidemic" of sexual violence. The federal government setup another Committee to review existing laws and suggest amendments to the criminal law relating to sexual violence. The Committee was composed of Justice J.S. Verma, Justice Leila Seth (both retired judges), and Senior Advocate Gopal Subramanium. Working on a self-imposed deadline of one month, the Committee sought proposals from activists, scholars, lawyers, and jurists in India and across the globe. ${ }^{38}$ It submitted a 627-page report within 29 days that contained some ambitious recommendations to reform the Indian criminal justice system. ${ }^{39}$

The Committee report made progress in redefining rape as an issue of bodily integrity and sexual autonomy rather than an attack against the honor of a woman's family or the wider community. ${ }^{40}$ In keeping with the spirit of the protests, its recommendations were framed within the discourse of the right to sexual autonomy and bodily integrity instead of the traditional notions of "Indian womanhood" based on chastity, conservative sexual morality, honor, and purity that had been engrained in the legal language relating to sexual violence. ${ }^{41}$

The committee proactively called for participation from women's organizations leading to a more intense engagement between the feminist movement and the State. The demands of these organizations did not coincide with the calls made by the social movements as their skepticism towards the State's monopoly on violence was very visible in these discussions. For example, several feminist interventions argued against increasing the age of consent from sixteen to eighteen years of age. ${ }^{42}$ Increasing the age of consent, they argued, would widen the ambit of sexual governance and criminalize consensual sexual relationships among teenagers. ${ }^{43}$

Feminist organizations also called for intersectional considerations. These groups were concerned with the scope of the term "custody" in demarcating the line between aggravated and

\footnotetext{
${ }^{37}$ Nilanjana Bhowmick, India: After New Delhi Gang Rape, Should the Culprits Be Executed?, Time (Dec. 26, 2012), https:// world.time.com/2012/12/26/india-after-new-delhi-gangrape-should-the-culprits-be-executed/; Rana, supra note 33, at 143 .

${ }^{38}$ For instance, the Policy Taskforce called "Beyond Gender Equality" was set up at Harvard University to advise the Indian government on how to best implement the report (Harvard College Women's Centre, 2013).

${ }^{39}$ Justice J.S. Verma et al., Report of the Committee on Amendments to Criminal Law (Jan. 23, 2013), https://www.prsindia. org/uploads/media/Justice\%20verma\%20committee/js\%20verma\%20committe\%20report.pdf.

${ }^{40}$ Verma et al., supra note 39, at 94.

${ }^{41}$ Kapur \& Cossman, supra note 6, at 282.

${ }^{42}$ See All India Democratic Women's Association \& Women's Groups, Submissions to Justice Verma Committee, FEMINIST LAW ARChives, (Jan. 4, 2013), http://feministlawarchives.pldindia.org/wp-content/uploads/submissions-by-allindia-democratic-women.pdf; Forum Against the Oppression of Women (FAOW), Aawaaz-e-Niswaan (voice of women) (AEN), Lesbians and Bisexuals in Action (LABIA), \& Mumbai, Submissions to Justice Verma Committee, FEMINIST LAW ARCHIVES, http://feministlawarchives.pldindia.org/wp-content/uploads/submissions-by-forum-against-the-oppression-ofwomen.pdf; Jagori, Submission to the Justice Verma Commission, Feminist LAW ArCHIVES (Jan. 4, 2013), http:// feministlawarchives.pldindia.org/wp-content/uploads/submissions-by-jagori.pdf; Lawyers Collective, Submission to Justice Verma Committee, FEMINIST LAW ARCHIVES, http://feministlawarchives.pldindia.org/wp-content/uploads/submissions-bylawyers-collective.pdf.

${ }^{43}$ Latika Vashist, Age of Consent and the Impossibility of Child Sexuality, INDIA SEMINAR 721, (2019), https://www.indiaseminar.com/2019/721/721_latika_vashist.htm.
} 
non-aggravated forms of sexual assault in Section 375 of the Indian Penal Code. The meaning of "custody" was limited to police officials, public servants, management or staff of a jail or women's or children's institutions, ${ }^{44}$ and triggered a presumption of non-consent. Feminists asserted that personnel of the armed forces and paramilitary forces should also be included to account for the atrocities in conflict areas like Jammu, Kashmir, and Manipur. ${ }^{45}$ Further, some feminists called for caste-based sexual atrocities to be identified as aggravated sexual assault, thereby acknowledging caste as an additional layer of marginalization. ${ }^{46}$ There was a continuing, clear consensus among feminist groups concerning the deletion of the exception for marital rape. Unlike earlier reports, the Verma Committee recommended removing the exception. ${ }^{47}$

All intervening feminist organizations departed from protestors' calls for capital punishment in rape cases. Rejecting this harsher form of punishment, feminists argued that there was no evidence supporting the claim that the death penalty has a deterrent effect; on the contrary, they cited studies showing that conviction rates fall as the severity of the punishment increases. ${ }^{48}$ The Justice

\footnotetext{
${ }^{44}$ Section 376 provides punishment for sexual assault. Clause 2 specifically deals with police officers, public servants, who can be sentenced with rigorous imprisonment for a term which shall not be less than ten years, but which may extend to imprisonment for life and shall also be liable to fine which shall not be less than fifty thousand rupees. PEN. CoDE. $\$$ 376, cl. 2 (India).

${ }^{45}$ See All India Democratic Women's Association \& Women's Groups, Submissions to Justice Verma Committee, FEMINIST LAW ARCHIVES, (Jan. 4, 2013), http://feministlawarchives.pldindia.org/wp-content/uploads/submissions-by-all-indiademocratic-women.pdf; Forum Against the Oppression of Women (FAOW), Aawaaz-e-Niswaan (voice of women) (AEN), Lesbians and Bisexuals in Action (LABIA), \& Mumbai, Submissions to Justice Verma Committee, FEMINIST LAW ARCHIVES, http://feministlawarchives.pldindia.org/wp-content/uploads/submissions-by-forum-against-the-oppression-ofwomen.pdf; Jagori, Submission to the Justice Verma Commission, Feminist LAW ARCHIVES (Jan. 4, 2013), http:// feministlawarchives.pldindia.org/wp-content/uploads/submissions-by-jagori.pdf; Saheli Women's Resource Centre, Delhi, Submissions to Justice Verma Committee, FEMINIST LAW ARCHIVES (Jan. 5, 2013), http://feministlawarchives.pldindia.org/ wp-content/uploads/submissions-by-saheli-women.pdf; Vrinda Grover, Submissions to Justice Verma Committee, FEMINIST LAW ARCHIVES (Jan. 5, 2013), http://feministlawarchives.pldindia.org/wp-content/uploads/submissions-by-vrinda-grover. pdf?; People's Vigilance Committee on Human Rights (PVCHR) to the Justice Verma Committee Report, FEMINIST LAW ARCHIVES, http://feministlawarchives.pldindia.org/wp-content/uploads/submissions-by-pvchr.pdf.

${ }^{46}$ See All India Democratic Women's Association \& Women's Groups, Submissions to Justice Verma Committee, FEMINIST LAW ARCHIVES, (Jan. 4, 2013), http://feministlawarchives.pldindia.org/wp-content/uploads/submissions-by-all-indiademocratic-women.pdf?; Forum Against the Oppression of Women (FAOW), Aawaaz-e-Niswaan (voice of women) (AEN), Lesbians and Bisexuals in Action (LABIA), \& Mumbai, Submissions to Justice Verma Committee, FEMINIST LAW ARCHIVES, http://feministlawarchives.pldindia.org/wp-content/uploads/submissions-by-forum-against-the-oppression-ofwomen.pdf?; Jagori, Submission to the Justice Verma Commission, Feminist LAW ArCHIVES (Jan. 4, 2013), http:// feministlawarchives.pldindia.org/wp-content/uploads/submissions-by-jagori.pdf?; Saheli Women's Resource Centre, Delhi, Submissions to Justice Verma Committee, FEMINIST LAW ARCHIVES (Jan. 5, 2013), http://feministlawarchives.pldindia.org/ wp-content/uploads/submissions-by-saheli-women.pdf?; Vrinda Grover, Submissions to Justice Verma Committee, FEMINIST LAW ARCHIVES (Jan. 5, 2013), http://feministlawarchives.pldindia.org/wp-content/uploads/submissions-byvrinda-grover.pdf?; People's Vigilance Committee on Human Rights (PVCHR) to the Justice Verma Committee Report, FEMINIST LAW ARCHIVES, http://feministlawarchives.pldindia.org/wp-content/uploads/submissions-by-pvchr.pdf?.

${ }^{47}$ Verma et al., supra note 39 , at 113.

${ }^{48}$ Verma et al., supra note 39. See also Forum Against the Oppression of Women (FAOW), Aawaaz-e-Niswaan (voice of women) (AEN), Lesbians and Bisexuals in Action (LABIA), \& Mumbai, Submissions to Justice Verma Committee, FEMINIST LAW ARCHIVES, http://feministlawarchives.pldindia.org/wp-content/uploads/submissions-by-forum-against-the-oppressionof-women.pdf; Jagori, Submission to the Justice Verma Commission, Feminist LAW ArChIVES (Jan. 4, 2013), http:// feministlawarchives.pldindia.org/wp-content/uploads/submissions-by-jagori.pdf?; Saheli Women's Resource Centre, Delhi, Submissions to Justice Verma Committee, FEMINIST LAW ARCHIVES (Jan. 5, 2013), http://feministlawarchives.pldindia.org/ wp-content/uploads/submissions-by-saheli-women.pdf; Vrinda Grover, Submissions to Justice Verma Committee, FEMINIST LAW ARChIVES (Jan. 5, 2013), http://feministlawarchives.pldindia.org/wp-content/uploads/submissions-by-vrinda-grover. pdf; People's Vigilance Committee on Human Rights (PVCHR) to the Justice Verma Committee Report, FEMINIST LAW ARCHIVES, http://feministlawarchives.pldindia.org/wp-content/uploads/submissions-by-pvchr.pdf?; Amnesty International, Submission to the Justice Verma Committee, FEMINIST LAW ARCHIVES (Jan. 4, 2013), http://feministlawarchives.pldindia. org/wp-content/uploads/submissions-by-amnesty-international.pdf; Alternate Law Forum, Bangalore, Submission to Justice Verma Committee, FEMINIST LAW ARCHIVES, http://feministlawarchives.pldindia.org/wp-content/uploads/submissions-byalternative-law-forum.pdf.
} 
Verma Committee report endorsed this position and recommended that capital punishment not be introduced for rape cases.

As evident from these recommendations, the Indian feminist engagement with the law has been skeptical of the Indian state's claim to power in the name of justice. This apprehension with state power can be dated back to the genesis of the Indian woman's movement, which began during the emergency. ${ }^{49}$ The widespread opposition of feminists to the issue of the death penalty and increasing the age of consent shows that it has always been aware of the consequence of carceral politics on criminal law.

\section{An Empty Promise: Criminal Law Amendments of 2013}

Like on earlier occasions, one witnessed a watering down of feminist recommendations. The Criminal Law Amendment Act of 2013 (CLA) skipped each of the Committee's key recommendations that would have advanced the rights for gender equality and respect for women. ${ }^{50}$ The legal reforms elevated the issue of sexual violence to a state of emergency. ${ }^{51}$ Pratiksha Baxi, a well-known feminist scholar, correctly called the CLA a spectacle of legal reform enacted to detract attention from permanent states of emergency ${ }^{52}$ She refers to situations of everyday oppression, such as rapes by members of security forces in the conflict areas of Kashmir and Assan, marital rape exception, and routine violence on the Dalit women, as permanent states of emergency which were skipped in the reforms.

While the CLA imposed harsher punishments on perpetrators of rape and allowed for capital punishment in cases that result in death of the victim, it retained the language of outraging the modesty of women and ignored the role that caste, class, and ethnicity play in marginalization of the woman subject.

Although endorsed by the Justice Verma Committee report, Parliament did not heed the concerns of the women's movement and increased the age of consent from sixteen to eighteen. In doing so, the government privileged the protection of "Indian morality" over feminist calls to recognize the sexual agency of women. ${ }^{53}$ While addressing the call to criminalize marital rape, the Parliamentary Standing Committee argued that if marital rape was criminalized the "entire family system [would] be under greater stress and the committee may perhaps [do] more injustice". ${ }^{54}$ Once again, at the center of the legislative discourse were not concerns about consent, but the institution of the family. The discourse privileges heteronormative marriage and perpetuates the embeddedness of rape in property and marriage regimes.

With respect to capital punishment, Parliament justified the introduction of the death penalty in rape cases by citing examples from the Middle East, Russia, and China. ${ }^{55}$ The rationale was that

\footnotetext{
${ }^{49}$ See generally Pratiksha Baxi, "Carceral Feminism” as Judicial Bias: The Discontents Around State v. Mahmood Farooqui, 3 INTERDISC. L. 1 (2016).

${ }^{50}$ It also created the offense of rape and sexual assault as a gender-neutral offense, for both perpetrators and victims, in everyday contexts as well as the aggravated rape cases-for example, gang rape and custodial rape cases. Unlike the report, the ordinance did not define sexual assault—non-consensual and non-penile penetration into bodily orifices-as having any gradations as to severity, nature, or impact. The ordinance also retains the two-finger test, and the past sexual history clause 3both controversial and critiqued by the report—-therefore continuing historical injustices in rape cases and trials and perpetuating rape myths.

${ }^{51}$ The amendment did not go through the standard parliamentary process, instead it was enacted by the government as an ordinance which is a form of executive decree issued in times of emergency.

${ }^{52}$ Pratiksha Baxi, The Emergency Continues: The Ordinance on Sexual Assault, KAFILA (Feb. 3, 2013), https://kafila.online/ 2013/02/03/the-official-emergency-continues-the-ordinance-on-sexual-assault-pratiksha-baxi/.

${ }^{53}$ Flavia Agnes, Controversy Over Age of Consent, 48 ECON. \& POL. WKLY. (2013).

${ }^{54}$ Standing Committee on Home Affairs, Report on The Criminal Law (Amendment) Bill, 2012 (Dec. 2015), http://164.100. 47.5/newcommittee/reports/EnglishCommittees/Committee\%20on\%20Home\%20Affairs/167.pdf.

${ }^{55}$ See Neha Thirani, Debating the Death Penalty for Rape in India, N.Y. TIMEs (Dec. 28, 2012), https://india.blogs.nytimes. com/2012/12/28/debating-the-death-penalty-for-rape-in-india/ (writing on the leader of opposition, Sushma Swaraj).
} 
the availability of the death penalty in cases of brutal rape allegedly contributed to the reduction of rape in these countries. This argument was in direct opposition to the submissions of several feminist groups assisting the Justice Verma Committee and the Justice Verma Committee report itself.

There is a consistent gap between the demands of the women's groups and the recommendations of the Law Commission and committee reports, and further between the Commission's suggestions and legislative amendments. There were certain breakthroughs as far as the definition of rape and the affirmative standard of consent was concerned. However, feminist critiques concerning the marital rape exception and the need for intersectionality, which called into question the structures of family and caste, were not addressed. The response of the legislature seems to negotiate between the rights-based discourse and the hegemonic social processes like caste and familial dynamics. ${ }^{56}$

What the women's rights groups achieved was recognition of their demands in the form of the Committee report. But the social movement that got them the bargaining power became one of the reasons why their demands were not met. As the State seemed to be catering to popular politics by addressing calls for retribution and more violence, ${ }^{57}$ a case can be made that the reforms did more harm than good. The following case analysis highlights how the resulting criminal law amendment, which was hailed as a transformative moment in the struggle to address sexual violence against women, was actually a regressive move that reaffirmed traditional norms and familial logic.

\section{Promises Unkept: Courts Interpreting the Criminal Law Amendments of 2013}

The most important part of the amendments in the CLA was with respect to consent. The legislature, by way of an Explanation to Section 375 of the Indian Penal Code, added that consent for the purposes of the said section would mean "unequivocal voluntary agreement." It explicitly ruled out passive submission as consent, thereby undoing the consequences of the Mathura Judgment where absence of active resistance was held as a sine qua non for rape. The introduction of the notion of affirmative consent was seen to have opened countless opportunities for the courts to construct consent in accordance with international standards. The affirmative consent standard requires an affirmative and voluntary agreement on the part of the victim, verbal or non-verbal, rather than consent simply being deduced or inferred from the passive conduct of a sexual partner. Feminist scholars in other jurisdictions have asserted that when affirmative standard of consent is understood as the threshold of rape, then the requirement for objective findings on the conduct and body of the victim is, to an extent, minimized. ${ }^{58}$

One of the first major instances where the courts sought to apply the new standard of affirmative consent under the CLA was in the case of State v. Mahmood Farooqui. ${ }^{59}$ The case involved the rape of a 35-year-old Columbia University researcher who was visiting India for her field work. She alleged that Mahmood Farooqui, a well-known writer and theater personality, forced oral sex upon her.

The lower court conceptualized rape as "a sin and taking what was most precious to her, [that is] her control over her sexuality." ${ }^{60}$ Such theorization of rape is a break from the dominant discourse of rape being understood as a loss of honor. The court held that:

\footnotetext{
${ }^{56}$ Pratiksha Baxi, Legacies of Common Law: "Crimes of Honour” in India and Pakistan, 27 THIRD WORLD Q. (2006).

${ }^{57}$ Poloumi Roychowdhary, Over the Law: Rape and the Seduction of Popular Politics, 30(1) GENDER \& SOC'Y 80-94 (2016).

${ }^{58}$ Sharon Cowan, Freedom and Capacity to Make a Choice: A Feminist Analysis of Consent in Criminal Law of Rape Cases, in Sexuality and the Law: Feminist Engagements 65 (Vanessa E. Munro \& Carl F. Stychin eds., 2007).

${ }^{59}$ State v. Mahmood Farooqui, (2016) SC 118/15 (India).

${ }^{60} I d$. at 75 .
} 
The essence of rape is absence of consent. Consent means an intelligent, positive concurrence of the woman. A woman is said to consent, only when she freely agrees to submit herself, while in free and unconstrained possession of her physical or moral power to act in a manner she wanted. Submissions under the influence of fear or terror or false promise is not consent. $^{61}$

It is important to note here that the court in the case has set affirmative consent as a standard for sexually intimate relationships. It acknowledges that even if the victim and the accused were in sexually intimate relationship, active participation by the victim is required for consensual sex. The court acknowledges the fact that a rape victim may have frozen due to fear or sheer shock, especially when rape is committed by a person who is known to the accused. ${ }^{62}$ The court in this case also took into consideration additional emotional coercion, which may have played a role in determining the conduct of the victim. ${ }^{63}$

This break from dominant discourse triggered varied responses from feminist scholars. On one hand, some feminists hailed it as a progressive shift. ${ }^{64}$ On the other hand, some used this as an opportunity to highlight the dangers of this approach becoming draconian and the possibility of diluting due process clauses and giving more power to the punitive State. ${ }^{65}$

However, these discussions around the trial court judgment soon became redundant in light of reasoning given by the Delhi High Court in its appeal to the Farooqui case. ${ }^{66}$ The court, while focusing on the previous sexual encounters between the accused and the victim, held that the unwillingness of the victim was in her own mind and heart, and was not communicated to the accused. The court took into consideration that on previous occasions the victim had consented to kissing, therefore her "no" would have to be more emphatic in other circumstances. This is a perfect illustration of the phallocentric nature ${ }^{67}$ of the rape trial where if a woman consents to certain level of intimacy, sexual complicity for subsequent assault is presumed. ${ }^{68}$ The "rational" binary logic that the law follows cannot seem to comprehend that a woman may agree to certain kinds of intimacy but not sexual intercourse.

The court held that:

It is not unknown that during sexual acts, one of the partners may be a little less willing or, it can be said unwilling but when there is an assumed consent, it matters not if one of the partners to the act is a bit hesitant. Such feeble hesitation can never be understood as a positive negation of any advances by the other partner. ${ }^{69}$

\footnotetext{
${ }^{61} I d$. at 54.

${ }^{62} I d$. at 16 .

${ }^{63} \mathrm{Id}$. at 84 .

${ }^{64}$ Nivedita Menon and J. Devika praised the reasoning by arguing that the judgment inscribed rape as a crime against "the person's control over her body, her sexual identity and sexual choice” and not honor or shame. See Nivedita Menon \& J. Devika, The Mahmood Farooqui Rape Conviction: A Landmark Judgment, KAFILA (Aug. 14, 2016), https://kafila.online/ 2016/08/14/the-mahmood-farooqui-rape-conviction-a-landmark-verdict-j-devika-nivedita-menon/.

${ }^{65}$ Manisha Sethi, a noted civil rights activist, argued that the judgment was an example of "carceral feminism and its unspoken alliance with a punitive state." She asserts that the case does not prove the guilt of the accused beyond reasonable doubt as the possibility of the crime within a span of two minutes was very unlikely. See Manisha Sethi, Why the Mahmood Farooqui Judgment is Deeply Flawed, Hardnews (Sept. 8, 2016), http://archives.hardnewsmedia.com/2016/08/whymahmood-farooqui-judgment-deeply-flawed.

${ }^{66}$ Mahmood Farooqui v. State, (2017) Delhi HC 2901 (India).

${ }^{67}$ The term phallocentricism does not only imply a culture which is structured by male imperatives but also refers to the dissolution of women's perspective in norms, ideals and models devised by men. If a particular discourse is phallocentric, it denies women any speaking position which is different from the male voice and disqualifies any other speech as a murmur or hysteria. For more discussion, see ElizABETH Grosz, JaCQues LaCAN: A Feminist InTroduction 174 (1990).

${ }^{68}$ Carol SMart, Feminism and the Power of LaW 44 (1989).

${ }^{69}$ Mahmood Farooqui vs. State, (2017) Delhi HC 2901, para. 47 (India).
} 
The dichotomy between a feeble and an emphatic "no" was in clear contravention to the affirmative consent standard which requires active participation by the woman. The CLA makes it clear that within the meaning of Section 375 IPC, consent has to be unambiguous. The amendment made a clean distinction between submission and consent. However, the court, in this case, creates a category of "assumed consent" which manifestly negates the feminist call for greater reciprocity in heterosexual relationships. ${ }^{70}$ At the heart of the discourse is the subjectivity of a man as the court relies on the perception of the man rather than the expression of the woman. The court did not inquire about the steps taken by the defendant to ascertain the meaningfulness of consent; in fact, the court legitimized the blatant disregard of the victim's expression by the defendant.

The judgment is marked by the erasure of a woman's voice from the juridical discourse. The court, while interrogating mens rea, creates another distinction between "persons of letters" and a woman who does not know "the way of the world."71 It held that because the "no" was not an emphatic one that is expected of a woman who is intellectually proficient, the accused thought of it as consent. It states:

Instances of woman behavior are not unknown that a feeble "no" may mean a "yes." If the parties are strangers, the same theory may not be applied. If the parties are in some kind of prohibited relationship, then also it would be difficult to lay down a general principle that an emphatic "no" would only communicate the intention of the other party. If one of the parties to the act is a conservative person and is not exposed to the various ways and systems of the world, mere reluctance would also amount to negation of any consent. But same would not be the situation when parties are known to each other, are persons of letters and are intellectually/academically proficient, and if, in the past, there have been physical contacts. In such cases, it would be really difficult to decipher whether little or no resistance and a feeble "no," was actually a denial of consent. ${ }^{72}$

Here the court places an undue burden on the "intellectually/academically proficient woman" to assert herself emphatically and to resist in the right manner. The judgment requires her to show physical resistance, as for her, passive submission would be deemed as consent. ${ }^{73}$ It is interesting to note that even though resistance is no longer a sine qua non in rape, it remains a crucial preoccupation of the court. In 2018, the Supreme Court dismissed the appeal challenging the acquittal of the accused. ${ }^{74}$

Therefore, the Farooqui judgment ultimately reversed the advancements made by the CLA. It reinscribes the picture of an ideal rape victim and the aggressive male seducer that still haunts the juridical construction of consent. It manifests the tension between feminist calls for reforms and the interpretative violence of the law. It demonstrates how every act of interpretation runs the risk of undoing the all too certain image of the law-which still struggles with the question of a sexually autonomous woman alleging assault.

Beyond the courtroom, the understanding of mens rea in sexual violence cases has also preoccupied the feminist discourse in India. The CLA, and arguably also the judgment, has also been critiqued on the question of consent. Prabha Kotiswaran, a prominent feminist scholar, noted the importance of considering "honest and reasonable belief" on the part of the accused while

\footnotetext{
${ }^{70}$ Vanessa E. Munro, Constructing Consent: Legislating Freedom and Legitimating Constraint in the Expression of Sexual Autonomy, 41 AKron L. Rev. 924 (2009). Munro asserts that the affirmative consent standard forges mutual reciprocity in relationships. It entails "generating attitudinal changes that may, in time, permit holding defendants to a higher level of accountability in regard to their sexual communication strategies."

${ }^{71}$ Mahmood Farooqui, (2017) Delhi HC 2901 at para. 78.

${ }^{72}$ Mahmood Farooqui, (2017) Delhi HC 2901 at para. 78.

${ }^{73}$ Pratiksha Baxi, When 'No' is Not 'No' in Law, The WIRE (Sept. 29, 2017), https://thewire.in/gender/law-no-may-notactually-mean-no.

${ }^{74}$ Ms. X v. Mahmood Farooqui \& Anr, (2018) SLP(Crl) -000281 (India).
} 
adjudicating rape cases. ${ }^{75}$ Thus, to establish mens rea in rape cases the prosecution would have to negate the presence of "honest and reasonable belief" on the part of the accused. However, that argument does not take into account the feminist critique of "honest and reasonable belief" being susceptible to gendered stereotypes. When determining the reasonability of a defendant's action, the courts are often informed by stereotypical gendered assumptions about socio-sexual interactions. ${ }^{76}$ For example, Munro and Finch prove through their empirical research in England that "several jurors agreed that it would be reasonable for the defendant to believe that the complainant was consenting to intercourse if she "had been drinking all night and flirting with him."'77 Contrarily, Mrinal Satish, a noted scholar, asserted that the sexual offense provision should be interpreted as a strict liability offense. ${ }^{78}$ Mistaken belief is not a defense that can be taken by the accused in rape cases. However, Latika Vashist, another feminist scholar, cautioned about the dangers of construing rape as a strict liability offense. ${ }^{79}$ She asserts that "excluding enquiry into accused's state of mind and exclusively focusing on the consent element solely from the perspective of the woman aligns well with the objectives of the 'carceral' criminal law project that is repressive." ${ }^{80}$ Theorizing rape as a strict liability offense would create a presumption of guilt against the accused, which in India, is a reminder of the draconian terror laws and deviates from the well-established principles of the criminal justice system.

This back and forth in the feminist circles suggested that any discussion on consent would have to creatively engage with the question of honest belief. However, at the same time, the problems with the liberal underpinnings of the notion of affirmative consent should not be forgotten. The manner in which questions regarding mens rea play out in court is as important a part of rape adjudication as adoption of affirmative consent standards.

On account of affirmative consent as well as interpretation of mens rea in sexual violence cases, the high court decision in the Farooqui case falls short of the promises of affirmative consent made by the 2013 CLA. The promises in the amendment and the minimal legislative developments meant nothing without the backing of progressive interpretation by the courts.

\section{Taking Account: Feminist Engagement with Criminal Law}

Outside the legal realm, a tangible outcome of the 2012 protests movement described above was that it brought feminist politics to the mainstream. With an increasing number of "Take Back the Night" marches ${ }^{81}$ and the proliferation of social media campaigns, ownership of the feminist struggle has become more decentralized. It is not just a concentrated agenda of a handful of activists, scholars, and NGOs. Arguably, it also paved the way for movements like \#MeToo campaigns to take their own shape in the specific context of India. ${ }^{82}$

\footnotetext{
${ }^{75}$ Prabha Kotiswaran, Governance Feminism in the Post Colony: Reforming India's Rape Laws, in Janet Halley, PrabHA Kotiswaran, Rachel Rebouche, \& Hila Shamir, Governance Feminism: An Introduction 115-16 (2018).

${ }^{76}$ Usha Ramanathan, Images (1920-1950): Reasonable Man, Reasonable Woman and Reasonable Expectations, in Engendering LaW: Essays In Honour of Lotika SARKar 33 (Amita Dhandaand \& Archana Parashar eds., 1999).

${ }^{77}$ Emily Finch \& Vanessa Munro, Breaking Boundaries: Sexual Consent in the Jury Room, 26 LEGAL STUD. 303, 315-16 (2006).

${ }^{78}$ Mrinal Satish, The Farooqui Judgment's Interpretation of Consent Ignores Decades of Rape-Law Reform and Catastrophically Affects Rape Adjudication, CARAVAN (Oct. 6, 2017), https://caravanmagazine.in/vantage/farooquijudgment-consent-ignores-rape-law-reform-catastrophically-affects-adjudication.

${ }^{79}$ For more discussion on mens rea concerning sexual violence offenses, see Latika Vashisht, Law, Violence, and Sexual Consent, in RETHINKING LAW AND Violence (Latika Vashist \& Jyoti Dogra Sood eds., 2020) (arguing that rape in India is a strict liability offense).

${ }^{80}$ Vashisht \& Sood, supra note 79 , at 298.

81 “Take Back the Night" marches have been used by women's groups across nations to raise public consciousness on issues sexual violence against women. The Indian rendition of these marches have been playing out on the streets of cities such as Delhi, Mumbai, Bangalore, and Chennai since 2014-15. The campaign resolves to reclaim public spaces and safety for women.

${ }^{82}$ Vashisht \& Sood, supra note 79.
} 
When applied by the court, the legislative victory of the inclusion of affirmative consent gave way to a regressive interpretation enabling the State to dictate the terms of women's sexuality. Similarly, outside the courtroom, the language of the liberal women's rights framework was appropriated by the State to advance its far-right agenda portraying the Muslim woman as vulnerable and in need of the masculinist protection of the State. ${ }^{83}$ This has further rendered it difficult for Muslim women who have been pushing for reform to navigate this space, as the Hindutva agenda has used this framework to paint the picture that minorities do not treat "their" women properly. This, in turn, has legitimized State intervention at the expense of their personal laws and traditions. ${ }^{84}$ Moreover, Dalit and Muslim women often find themselves the object of politics, but at the same time are unable to seek the intersectional consideration they deserve, given their specific situation.

Prominent feminist scholars have also argued against this brand of feminism, reasoning that the legal responses end up producing a strictly regulated sexual subject which can hardly be celebrated as a victory for women's rights. ${ }^{85}$ Instead, they result in the strengthening of surveillance techniques that have regulated sexual conduct.

One must be extremely careful not to conflate the demands of the anti-rape law movement and responses of the State. It must be emphatically stated that the feminist movement in India, in its post-colonial context, has always been skeptical of the State and its power to turn criminal law into a tool for surveillance. ${ }^{86}$ With memories of state emergency imposed in the mid-1970s still fresh, feminists vowed to take greater care with future demands lest they be used to curb civil liberties. ${ }^{87}$ Still, every campaign is centered around demands for the State, particularly in the form of legislative reforms. ${ }^{88}$ However, its efficacy and implications have been also questioned consistently. ${ }^{89}$

This is not to argue that any engagement in the criminal law framework is unwarranted or selfdefeating for the cause of protectioning women against sexual violence. Reliance on criminal law and legal reforms to seek social justice can be justified on many counts. The law serves the purpose of declaring practices illegal which were erstwhile considered acceptable in the society. In that sense, the court and the legislature act as platforms to place women's marginalization on the agenda of society in the hope that the criminalization and the subsequent deterrence will percolate into a change of societal practices. Legal reforms are imperative, for example, where law itself is used as a tool for oppression, as is in the case of the restrictive definition of consent discussed above.

Although the demands and intentions of the feminist movement may not be explicitly carceral, it is undeniable that the unintended consequences of this engagement with the criminal law framework have done considerable damage to women's sexual autonomy. It is also emblematic of the crisis of a liberal subject which is at the center of criminal law. We argue in the next section how this constant struggle with the State could end, if the feminist movement dropped its

\footnotetext{
${ }^{83}$ See generally Kapur, supra note 7 , at 29.

${ }^{84}$ Kalpana Kannabiran, India, in Feminist Advocacy, Family LaW and Violence Against Women: InTERnational Perspectives (Mahnaz Afkhami et al. eds., 2019), http://kalpanakannabiran.com/pdf/Family-Law-Reform-Kannabiran. pdf. In the pretext of furthering the feminist agenda, the state was able to successfully challenge the practice of Triple Talaq before the Supreme Court.

${ }^{85}$ Angela Davis \& Gina Dent, Prison as a Border: A Conversation on Gender, Globalization, and Punishment, 26.4 SIGNS: J. Women In Culture \& SoC'y 1235 (2001); Kapur, supra note 7.

${ }^{86}$ See generally Prabha Kotiswaran, A Bittersweet Moment Indian Governance Feminism and the 2013 Rape Law Reforms, 51 ECON. \& POL. WeEKLY 79-87 (2017).

${ }^{87}$ See generally Nandita Haskar, Human Rights Lawyering: A Feminist Perspective, in ENGENDERING LAW EsSAYS IN HONOR OF LOTIKA SARKar 71-88 (Amita Dhanda \& Archana Parashar eds., 1999).

${ }^{88}$ See for example, Dowry Prohibition Act, 1961; Criminal Law Amendment, 1983 addressing domestic violence and prenatal sex selection.

${ }^{89}$ See generally Kapur \& Cossman, supra note 6; Richa Sharma \& Susan Bazilli, A Reflection on Gang Rape in India: What's Law Got to Do with It?, 3 InT'L J. Crime, Just. \& Soc. Democracy 4, 18 (2014).
} 
exclusive focus on the State and instead engaged with the collective responsibility of society to sustainably address manifestations of structural injustice.

\section{Expansion from Fault-Based Liability to Relational Responsibility}

Social movements and women's rights groups restricting themselves to legal solutions is a case of limited imagination. The scope of a solution in the form of an amended criminal law provision does not address the entirety of the scope of structural injustice against women. Those demands do not include building democratic institutions that distribute social, economic, and political power more equitably to address the structural injustice which leads to rampant incidents of sexual violence in the first place. ${ }^{90}$ Such engagement is ignorant of intersectional feminist approaches and the acknowledgment that feminists can also contribute to or reproduce power inequalities.

Offenses concerning sexual violence against women are not just a transgression of the moral code of a society that can be met with sanctions to create the desirable deterrence effect. Rampant sexual violence that the masses were protesting is a symptom of a deeply rooted social inequality. Strengthened law enforcement, stricter punishments, and new offenses have consistently failed to address the problem of sexual violence, both at homes and in public. The increasing number of cases of sexual and gender-based violence speaks for itself. ${ }^{91}$ Therefore, feminist strategies that seek declaration of rights and legislative reforms that prosecute sexual violence only serve a limited, albeit important, purpose.

In order to address social injustices, it is imperative for feminist social movements as well as rights groups to look at forward-looking models of responsibility. These models go beyond the antagonistic state-centered modes of establishing liability and punishing the perpetrator of sexual violence as deviants, and, instead, focus on systems and institutions that perpetuate these behaviors. Relational theories offer more nuanced modes of addressing structural injustices.

Iris Marion Young has offered a comprehensive definition of oppression that leads to structural injustice which could be used as a frame of reference to explore the space for potential extra-legal reforms to achieve social justice. In building her seminal relational theory of justice, Young has defined structural injustice as a situation when:

[S]ocial processes put large categories of persons under a systematic threat of domination or deprivation of the means to develop and exercise their capacities, at the same time as these processes enable others to dominate or have a wide range of opportunities for developing and exercising their capacities. ${ }^{92}$

These institutionalized processes, according to Young, establish structural injustice which is:

[A] kind of moral wrong distinct from the wrongful action of an individual agent or the willfully repressive policies of a state. Structural injustice occurs as a consequence of many individuals and institutions acting in pursuit of their particular goals and interests, within given institutional rules and accepted norms. ${ }^{93}$

\footnotetext{
${ }^{90}$ See generally Angela Davis, Abolition Democracy 9 (2005).

${ }^{91}$ National Crimes Records Bureau's Report on Crimes in India, 2019 reported an average of 87 rape cases daily in 2019 and overall 4,05,861 cases of crime against women during the year, a rise of over $7 \%$ from 2018. See National Crime Records Bureau, Ministry of Home Affairs, Crime in India (Sept. 30, 2020), https://ncrb.gov.in/sites/default/files/CII\%202019\% 20Volume\%201.pdf.

${ }^{92}$ Iris Marion Young, Responsibility and Global Justice: A Social Connection Model, HANDBOOK OF ReSEARCH ON GLOBAL Corporate Citizenship 137-65, 147 (2008).

${ }^{93}$ Young, supra note 92.
} 
Any structural injustice, according to Young, is sustained by oppression and domination. She defines the two basic critical concepts as follows: "oppression, the institutional constraints on self-development, and domination, the institutional constraint on self-determination." 94 According to her, there can be five fundamental forms of oppression-exploitation, marginalization, powerlessness, cultural imperialism and violence-which are the criteria for assessing whether an actual individual or group is oppressed or not. ${ }^{95}$ Domination on the other hand, places constraints on self-determination by applying institutional conditions which limit individuals in their participation in decision-making and designating conditions for action. ${ }^{96}$

The oppression of women as a social group goes beyond the physical and sexual violence they face on the streets. An anti-rape movement cannot blind itself to the fact that this is a manifestation of an unjust power structure. Structural injustice is a result of sustained oppression and domination and not a mere act of one person or perpetrator or which can be addressed by prosecution, or even prevention, by the State or a law enforcement agency. It is a result of many individuals and institutions who are within the institutional rules and accepted norms of domination and take the given norms as accepted, which then perpetuates oppression. Any feminist vision of a just society and sustainable solutions against gendered violence must see this as their starting point.

The central reason behind situating the case of Jyoti Singh and the subsequent protests in the framework of structural injustice is to elevate sexual violence to a kind of moral wrong distinct from the wrongful action of an individual agent. This requires a fundamental change in the focus of social movements from a liability, or guilt, framework to a responsibility framework.

Young builds her theory on a "social connection model of responsibility," ${ }^{97}$ which emphasizes the fact that when we focus on holding one, or a few, guilty for the moral wrong they have committed, we exclude the responsibility of the collective because they were not directly involved in the wrongful act. ${ }^{98}$ The collective may not be responsible for the offense or the act of violence per se as the perpetrator, but they share the responsibility of having taken part in the process of creating these inherently unjust structures. Therefore, the criminal liability model cannot entirely address a case of structural injustice. The attribution of responsibility of the collective in relation to structural injustice comes with a forward-looking obligation to collectively "transform the structural processes to make their outcomes less unjust." 99

Young has explicated her argument in a context of structural injustice that a poor woman is subjected to in terms of the system perpetuating her condition of poverty. In the situation of homelessness, there may not be an individual agent who is particularly responsible for her poverty, but the collective society - not marked by national borders - is engaging in varying institutional processes which produce injustice. Consequently, she argues for a collective responsibility model over an isolating agent liability model.

However, in the context of sexual violence against women, one must highlight the distinct double-layered nature of the acts in question. Rape is, in its most bare form, an offense which is a manifestation of a structurally unjust and unequal system. At any given point, it is both an immediate violation of the bodily integrity of a woman and an act embedded in structural injustice. The latter should be the primary concern of a feminist movement seeking a just society, whereas the preceding engagement with the State indicates only the concern for the former. Sexual violence against women requires a dual response in the form of liability and responsibility: liability of the individual who committed the wrong - which is primarily the responsibility of the state, but this

\footnotetext{
${ }^{94}$ IRIs Marion Young, Justice AND the Politics OF Difference 39-65 (1990).

${ }^{95}$ Young, supra note 94.

${ }^{96}$ Young, supra note 94.

${ }^{97}$ IRIS MARION YOUNG, RESPONSIBILITY FOR JUSTICE (2011).

${ }^{98}$ Young, supra note 97, at 104.

${ }^{99}$ Young, supra note 97 , at 96.
} 
liability is mired within the shared collective responsibility to ameliorate the conditions which lead to this abuse. It is time that the social movements as well as the women's rights groups also focus on necessary structural responses in addressing the institutions that perpetuate the patriarchal rules of dominance resulting in widespread sexual violence.

\section{E. Conclusion}

Social movements have historically played a significant role in empowering the social, economic, and political status of women in India. Protests and marches on the streets continue to be one of the most important tactics for setting an agenda in a deliberative democracy. While often working hand in hand with women's rights groups, sometimes the distinction in their demands can be detrimental to the cause of protection of women against sexual violence.

We argue that it is imperative that the Indian women's movement-social movements as well as women's rights groups-drop their narrow focus on criminal law and misplaced belief in the idea that creation of new offenses and the declaration of more rights is the most important pathway to sustainably addressing sexual violence against women. Although, criminal liability plays a role in securing justice for the violations of fundamental rights relating to life and body. However, in this article, we take account of the intended and unintended consequences of feminist engagement with the State in the framework of the criminal law. We build on Iris Marion Young's theory on relational responsibility for structural justice to argue that focusing exclusively on the punishment of individual agents who have committed certain wrongs will not ameliorate structural injustices. Any demand for sustainable social reforms needs to be built on forward-looking models of responsibility aiming for collective transformation of social structures that perpetuate and enable structural injustice against women.

Cite this article: Mehta K, Tiwari A (2021). Between Sexual Violence and Autonomy: Rethinking the Engagement of the Indian Women's Movement with Criminal Law. German Law Journal 22, 860-877. https://doi.org/10.1017/glj.2021.40 